\title{
INTENTIONALLY “MIS-LEAD”
}

\section{Environmental Racism in Flint, Michigan}

RACHEL LOOS

BEGINNING IN 2014, A SERIES OF PATTERNS OF NEGLIGENCE BY OFFICIALS LED TO THE FLINT WATER CRISIS, IN WHICH THE RESIDENTS OF FLINT, MICHIGAN WERE EXPOSED TO TOXIC LEVELS OF LEAD IN THE DRINKING WATER. THIS WILL HAVE LONG-LASTING, DETRIMENTAL EFFECTS, ESPECIALLY ON THE CHILDREN OF FLINT. WHAT WAS DONE TO THE PEOPLE OF FLINT IS NOT AN ISOLATED INCIDENT, BUT A SYMPTOM OF THE LARGER ISSUE OF ENVIRONMENTAL RACISM IN THE UNITED STATES. HISTORICALLY, THROUGH THE PRACTICE OF REDLINING, THE FEDERAL HOUSING ADMINISTRATION HAS SYSTEMATICALLY SEGREGATED PEOPLE OF COLOR TO LESS DESIRABLE LAND. TODAY, RACIAL MINORITY COMMUNITIES ARE MORE LIKELY TO LIVE IN HOUSING NEAR HAZARDOUS WASTE FACILITIES AND SEWER TREATMENT PLANTS. ACROSS THE UNITED STATES, UNSAFE AND LEAD-TAINTED WATER IS A HUGE ISSUE FOR POOR COMMUNITIES OF COLOR. FLINT, MICHIGAN SERVES AS AN EXAMPLE OF HOW INSTITUTIONALIZED ENVIRONMENTAL RACISM HAS CONTRIBUTED TO EXTREME HEALTH CRISES FOR ENTIRE COMMUNITIES IN THE U.S. 
In a $2016 \mathrm{CNN}$ video, eight-year-olds Julian Folgham and Nadia Baylor talk excitedly while playing with their "Jake and the Never Land Pirates" figurines. The children and their toys are sprawled out on a pink carpet, in a room with wood paneled walls and bare wires along the windowsill. Both children are black. Julian has dark curls, and Nadia wears braids that end in plastic hair clips. They seem like normal children, carefree in their game, until reporter Sara Sidner asks them about the water. Nadia's face turns serious as she says "the water is poison" (Simon and Sidner). Nadia has reason for reacting so strongly. The water that flows from the taps in her home in Flint, Michigan was once tainted with lead.

Nadia Baylor's home appears to have not been renovated in a long time: the decor in the video reflects a style popular in the I96os. Back then, Flint was a booming metropolis, fueled by the prosperity of numerous General Motor (GM) factories in the area. In the mid 2oth century, the goodpaying manufacturing jobs at GM attracted many working class people to Flint, especially African Americans from the south. The growing population and the dumping of toxic waste in the Flint River led city officials to purchase Lake Huron water from the Detroit Water and Sewerage Department (DWSD) (Felton; Kennedy). Over the years most of the automotive plants closed, jobs moved overseas, and Flint-once known as "Vehicle City"-became "Murdertown, USA," with an underfunded police force and a homicide rate higher than Newark, St. Louis, and New Orleans in 2010 (LeDuff). Now more than 40 percent of residents live in households below the federal poverty line, and one in four is unemployed (Kennedy; Trounstine).

Flint is poor, but plenty of poor cities still provide safe water for inhabitants. What came to be known as the Flint water crisis, during which 99,000 people were affected by lead-tainted water - the full impact of which will not be known for many years-was caused by systemic environmental racism that has historically denied people of color basic resources (Fox). To fully understand, it is necessary to examine what happened in Flint leading up to the crisis. In 20I2, officials in the struggling city began planning to save money by switching from the DWSD water provider and building a pipeline to the Karegnondi Water Authority (KWA), which also supplies water from Lake Huron. In April of 20I4, while the pipeline to the KWA was being built, the city switched to the notoriously polluted Flint River as an interim source of water. A month later residents began complaining of the smell and color of the new water. After Escherichia coli (E. coli) and total coli- form bacteria were detected in the water, the city increased chlorine levels in an attempt to make it safe to drink (Kennedy). The difference in chemistry of the river water, coupled with this increase in chlorine, made the water highly corrosive to the protective coating on lead pipes.

Many of Flint's water pipes are made of lead, which is not necessarily a problem-an additive can be introduced to prevent the lead from leaching into the water. However, state officials did not immediately treat the Flint River Water to ensure it didn't cause corrosion, instead they waited to see what would happen. While the Michigan Department of Environmental Quality (MDEQ) insisted the water was safe to drink, the water was wearing away at lead pipes and poisoning the people of Flint (Kennedy; Smith; Trounstine). Officials continued reassuring people that the water was harmless, but many residents were concerned, and rightly so, as numerous people had reported illnesses, rashes, and even hair loss. Only after homes were tested for lead and city officials experienced scrutiny from the national media did Flint switch back to the DWSD, a full I8 months after the initial switch to the Flint River (Felton; Fonger; Kennedy).

By then, the damage had already been done. An independent test conducted by researchers from Virginia Tech found lead levels as high as 13,200 parts per billion $(\mathrm{ppb})$ in some homes, enough to categorize it as hazardous waste (Roy). By September 20I5, a study from the local Hurley Medical Center found that 2.I percent of children age five and under had elevated blood lead levels prior to

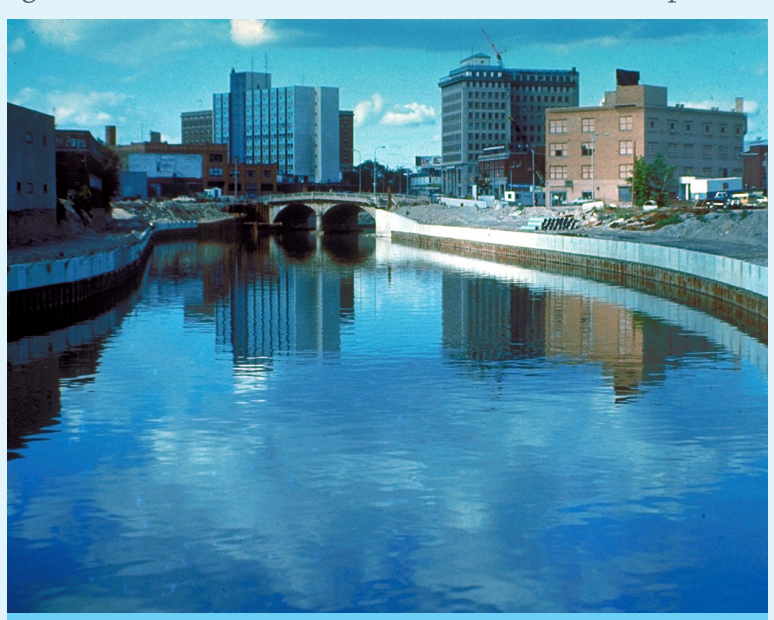

THE FLINT RIVER IN FLINT, MICHIGAN (COURTESY OF WIKIMEDIA COMMONS) 


\section{"Unfortunately, the Flint water crisis is not an isolated incident. It is merely one instance in a pattern of American cities segregating racial minorties to less desireable areas."}

the switch to Flint River water, compared to 4.0 percent after the switch (Roy). The Centers for Disease Control and Prevention (CDC) later analyzed over 7,000 children, and found that children who drank Flint water had a 50 percent higher risk of dangerously elevated blood lead levels than before the switch. It is still unclear how many children were affected, or what it could mean for their futures (Fox).

Unfortunately, the Flint water crisis is not an isolated incident. It is merely one instance in a pattern of American cities segregating racial minorities to less desirable areas, denying them vital resources, and failing to offer help when presented with evidence of this injustice. Clear evidence of this practice is in the distribution of hazardous waste sites in the United States. In I987, the United Church of Christ found that communities near commercial hazardous waste facilities have far higher proportions of people of color than communities without such facilities. Even when other socioeconomic characteristics of communities were taken into account, it was found that race was the single best predictor of the location of commercial hazardous waste facilities. After the report was released, Dr. Benjamin F. Chavis Jr. termed the racial biases in the location of commercial hazardous waste facilities "environmental racism," a phrase that can help characterize what has been happening to minority communities across the US for decades (Mohai and Bryant I63-64). Environmental racism has come to be associated with various studies demonstrating that racial minority communities are more likely to live in housing with leadbased paint and closer to freeways, sewer treatment plants, municipal and hazardous waste landfills, air pollution, and other environmental and health hazards (Foster 73I).

This did not happen by accident. Racism is often thought of as blatant, racially motivated actions by individuals, but since the creation of laws that punish this behavior, racism has become much more subtle and structural (Foster 733). The prejudiced behavior of individuals within government institutions can affect environmental racism, but as Michael Gelobter explains, discriminatory outcomes are an "interaction of internal processes, external structures and wider ideological and historical contexts and understandings" (Gelobter 74). Throughout the 2oth century, racism became gradually institutionalized with the help of the Federal Housing Administration (FHA). From its creation in I934 until the late I960s, the FHA overtly denied mortgages based upon race and ethnicity. This practice came to be known as "redlining" because red lines drawn on maps were used to delineate the areas where financial institutions would not invest (Madrigal).

The FHA helped many poor white people buy homes who otherwise could not have, but it influenced the segregation of whites and people of color in cities across the United States. Several FHA publications implied that different races should not share neighborhoods, and, according to James Loewen in his 2006 book Sundown Towns, repeatedly listed neighborhood characteristics like "inharmonious racial or nationality groups" alongside environmental disturbances "smoke, odors, and fog." This is an example of blatant racism, and while these guidelines do not still exist today, the general trend of separating the races has persisted. Over time, the FHA tended to isolate new, mostly white, residential developments to the edges of metropolitan areas creating suburbs, and stripping the inner city of a middle class. Older inner city neighborhoods, mainly populated by people of color, often fell into disrepair or abandonment. The demographics of cities and suburbs still reflect this trend, and the stereotypes of black street "thugs," and white suburban soccer moms still exist (Historical Shift). What began as overt racism slowly became institutionalized segregation within the housing industry, with effects that remain today.

Zoning policies, housing policies, and lending policies have contributed to the segregation of people of color and the poor. Though most recognize that racial discrimination is wrong, this has not translated into either decisionmaking or reformative policies. Like the rest of the U.S., segregation within Flint, Michigan has been ongoing for years, a result of both private discrimination and 


\section{"If Flint had been mostly white and wealthy, perhaps the authorities would have acted more quickly to solve the water issue."}

government policies that have forced people of color to remain in the same three or four neighborhoods within city limits, even as the city grew and other residents moved to the suburbs. By I970 these policies were changed, but the legacy remained (Demashkieh 3). Because it has only been a few decades, and because there was no active desegregation attempts, population demographics have tended to stay the same. Certain areas have remained largely white, while others tend to be inhabited by people of color. For example, 64 percent of Flint residents are people of color, but the city of Burton, directly to the east of Flint is made up of 86 percent white people (Trounstine).

Racial makeup is not the only difference between the two cities. Between 2007 and 2012 the recession affected municipal budgets, and many city governments saw expenditures fall. In Flint, spending decreased by $\$ 225$ per resident; in Burton it actually increased by \$I per resident. Skeptics will explain the difference in the cities by income: The median household income in Burton is $\$ 44,000$ a year, while the median income is just under $\$ 25,000$ a year in Flint. But this does not account for the fact that in 20 I4 Flint residents paid an average water bill of \$I4O while people in Burton paid $\$ 58$ (Trounstine). Burton inhabitants had clean, inexpensive water while Flint inhabitants paid more to be poisoned by lead-tainted water.

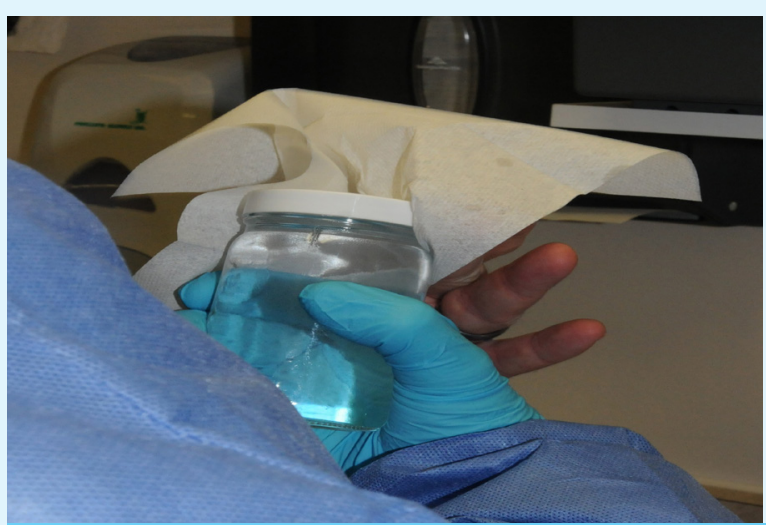

A SAM PLE OF WATER BEING TESTED FOR PURITY (COURTESY OF WIKIMEDIA COMMONS)
This is a result of decades of structural racism that has deprioritized supplying water to Flint. If Flint had been mostly white and wealthy, perhaps the authorities would have acted more quickly to solve the water issue.

What happened in Flint is nothing short of a tragedy. The biggest injustice has been done to the children of Flint, who will not experience the full results of this crisis for years to come. When Flint resident Lee-Anne Walters had her home tested for lead, she found that it had a lead content of Io4 parts per billion (ppb), (fifteen ppb is the Environmental Protection Agency's limit for lead in drinking water). Soon after, Walters' twin sons were diagnosed with lead poisoning (Roy). Two years later, the five-year-old boys are already showing developmental delays. The twins have hand-eye coordination issues, and one of the boys is significantly stunted in growth. Both struggle with remembering colors and the alphabet, and they have trouble communicating with other children (Gulledge).

It should not be surprising that lead poisoning has profound effects on a child's health and development. Lead is a neurotoxin: it kills neuron cells, damaging the central nervous system. There is significant evidence that childhood lead exposure can be detrimental to development. In a study of children in Cincinnati who were measured for blood lead levels throughout early childhood, those with high blood lead levels had lower brain volumes (Cecil et al. 74I-750). Lead exposure in childhood has also been associated with increased aggression and violence. Needleman and colleagues found that boys with high lead levels had higher teacher ratings of aggressive behavior and higher self-reported delinquency scores (363-69). Even children exposed to lead in utero are likely impacted. In a study of pregnant African American women, it was found that both prenatal and postnatal blood lead levels in offspring dramatically predicted adult criminal behavior and adult violence in the early twenties. For every 5 microgram increase in prenatal blood lead levels there was a 40 percent increase in the risk for arrest (Wright et al. 732-740). Flint has already earned the reputation of "Murdertown, U.S.A." Once the lead-poisoned children grow up, a greater rise in violent crime would be unsurprising. 
After the city of Flint switched back to its original water source, Mayor Karen Weaver declared a state of emergency over the elevated lead levels in the city's water. Michigan governor Rick Snyder and President Obama soon followed with their own declarations (Kennedy). In the years since, criminal charges were filed against three officials who neglected their duties, conspired to cover up evidence, and violated Michigan's Safe Drinking Water Act (Domonoske). Eventually, six more received criminal charges for misleading other officials about Flint's water treatment plan, which was not in compliance with lead and copper rules. Those responsible are beginning to face the consequences of poisoning the people of Flint, but things will likely never be the same again. Residents are understandably reluctant to drink the water from their taps again, and Governor Snyder has pledged to drink Flint water for 30 days to prove it is safe (Kennedy). The Flint water crisis left a community of people permanently shaken and distrustful of authority. Now they must anxiously wait for the neurocognitive deficits and other health problems to appear in their children, who will serve as an experiment on the impact of lead poisoning for the rest of their lives.

The problem of environmental racism extends far beyond Flint, Michigan. Economically and politically vulnerable black and Hispanic children still suffer disproportionately from the effects of lead in Baltimore, Maryland, Herculaneum, Missouri, Sebring, Ohio, and Washington, DC, where lead contamination crises are ongoing (Rosner and Markowitz). Unsafe and lead-tainted water is a huge issue for poor communities of color throughout the United States, a problem far more common than many people

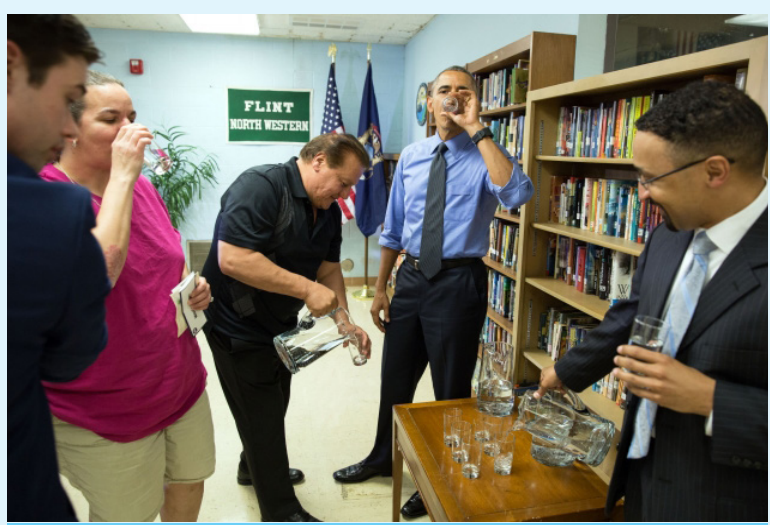

FORMER PRESIDENT BARACK OBAMA SIPS WATER FROM FLINT (COURTESY OF WIKIMEDIA COMMONS) think. Tests in multiple cities have shown dangerous levels of lead in the water, and Quest Diagnostics has found that more than 3 percent of 5 million children tested across the country had blood lead levels of more than five micrograms per deciliter of blood. Most inner city kids have blood lead levels that are detectable in their blood (Fox).

It is hard not to feel hopeless about the future after the injustice in Flint and the continuing environmental inequality throughout the nation. The good news is that the crisis in Flint has given many people insight into the problems within cities and the environmental racism that persists in our society. The socioeconomic and racial issues attached to the Flint water crisis have inspired people to take action who might not have engaged in environmental activism otherwise. Many people of color are displaying increased political mobilization around environmental issues. Organizations like the Citizens Clearing House for Hazardous Wastes (CCHW) and the National Toxins Campaign (NTC) work with over three thousand community groups, many of which are composed solely of people of color, others are composed of mixed social classes and races (Taylor 37). It is also encouraging that recent research in neuroscience has shown the links between lead and other social issues like violence and cognitive ability. Awareness must be raised as to how important a clean environment is in ensuring healthy development, so people can prioritize it more than they had before. What happened in Flint should serve as a stark reminder of the crucial role that access to clean water plays in social equality and personal dignity. 


\section{REFERENCES}

Cecil, Kim, et al. "Decreased Brain Volume in Adults with Childhood Lead Exposure." PLOS Medicine, vol. 5, 2008, pp. 74I-750.

Demashkieh, Rasha, et al. “The Flint Water Crisis: Systemic Racism Through the Lens of Flint." Michigan Civil Rights Commission, I7 Feb. 20I7. http://www.michigan.gov/ d o c u m e nts / m d cr / V FlintCrisis Re p- F Edited3-I3-I7-5543I7-7.pdf. Accessed 5 Dec. 20I7.

Domonoske, Camila. "3 Face Criminal Charges Over Flint Water Crisis." National Public Radio (NPR). 20 Apr. 2016. Web. 5 Dec. 2017.

Felton, Ryan. "What General Motors Did To Flint." Jalopnik. Gizmodo, 28 Apr. 20I7. Web. 27 Nov. 2017.

Fonger, Ron. "State Says Flint River Water Meets All Standards But More Than Twice the Hardness of Lake Water." MLive Media Group. Advance Digital, 23 May 2014. Web. 20 Nov. 2017.

Foster, Sheila. "Race(ial) Matters: The Quest For Environmental Justice Review Essay." Ecology Law Quarterly, vol. 20, I993, pp. 72I-753.

Fox, Maggie. "CDC Confirms Lead Levels Shot Up in Flint Kids After Water Switch.” NBC News. 24 Jun. 2oI6. Web. 6 Dec. 2017 .

Gelobter, Michael. "Toward a Model of 'Environmental Discrimination." Race and the Incidence of Environmental Hazards, edited by Paul Mohai and Bunyan Bryant, Westview Press, I992, pp. 64-8I.

Gulledge, Jacqueline. "Flint Water Crisis Leaves LongTerm Impact on Children's Health." Cable News Network (CNN). 3I Jan. 20I7. Web. 5 Dec. 20I7.

"Historical Shift from Explicit to Implicit Policies Affecting Housing Segregation in Eastern Massachusetts.” The Fair Housing Center of Greater Boston. Web. 5 Dec. 2017.

Kennedy, Merrit. “Lead-Laced Water in Flint: A Step-By-
Step Look at the Makings of a Crisis." National Public Radio (NPR). 20 Apr. 20I6. Web. 20 Nov. 2017.

LeDuff, Charlie. "Riding Along With the Cops in Murdertown, U.S.A.” New York Times. I5 Apr. 20II. Web. 4 Dec. 2017.

Loewen, James. Sundown Towns. Touchstone, 2006.

Madrigal, Alexis. "The Racist Housing Policy That Made Your Neighborhood." The Atlantic. The Atlantic Monthly Group, 22 May 20I4. Web. 4 Dec. 2017.

Mohai, Paul, and Bryant, Bunyan. "Environmental Racism: Reviewing the Evidence." Race and the Incidence of Environmental Hazards, edited by Paul Mohai and Bunyan Bryant, Westview Press, I992, pp. I63-76.

Needleman, Herbert, et al. "Bone Lead Levels and Delinquent Behavior." Journal of the American Medical Association, vol. 275, I996, pp. 363-369.

Nevin, Rick. "How Lead Exposure Relates to Temporal Changes in IQ, Violent Crime, and Unwed Pregnancy." Environmental Research, vol. 83, 2000, pp. I-22.

Rosner, David, and Markowitz, Gerald. "It's Not Just Flint. There's an Ugly History of Lead Poisoning and the Poor in the US." Mother Jones. Mother Jones and the Foundation for National Progress, I3 Feb. 20I6. Web. 20 Nov. 2017.

Roy, Siddhartha. "Pediatric Lead Exposure Presentation from Hurley Medical Center Doctors Concerning Flint, MI.” Flint Water Study, 24 Sep. 20I5. Web. 5 Dec. 2017.

Simon, Mallory, and Sidner, Sara. "Children of Flint: Inheriting Anxiety, Giving Up Hope.” Cable News Network (CNN), 7 Mar. 20I6. Web. 27 Nov. 20I7.

Smith, Lindsey. "After Ignoring and Trying to Discredit People in Flint, the State was Forced to Face the Problem. Michigan Radio. National Public Radio (NPR), I6 Dec. 20I5. Web. 20 Nov. 2017 .

Taylor, Dorceta. "Can the Environmental Movement Attract and Maintain the Support of Minorities?” Race and 
the Incidence of Environmental Hazards, edited by Paul Mohai and Bunyan Bryant, Westview Press, I992, pp. 28-

54 .

Trounstine, Jessica. "How Racial Segregation and Political Mismanagement led to Flint's Shocking Water Crisis." Washington Post, 8 Feb. 20I6. Web. 5 Dec. 2017.

Wright, John Paul, et al. "Association of Prenatal and Childhood Blood Lead Concentrations with Criminal Arrests in Early Adulthood." PLOS Medicine, vol. 5, 2008, pp. 732-740. 